\title{
Do Animals Have Souls?
}

\author{
Helmut F. Kaplan \\ Salzburg, Austria
}

Editors' Note: A shorter version of the following paper was presented in Oberwolfach, Germany in June, 1990, at a conference on the Souls of Animals organized jointly by the Schweitzer Center and Mobilization for Animals e. V.

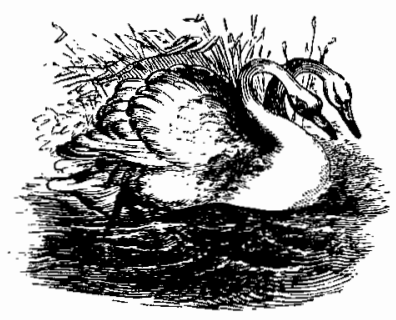

The question, whether animals have souls, is ambiguous. It can have a religious or a psychological meaning:

- Do animals have (immortal) souls?

- Do animals have inner life, i.e., do animals have subjective psychological experiences?

At first I was not very happy with these alternatives, because both questions seemed unpromising for several reasons. I just want to mention two of these reasons:

- Whether animals have immortal souls is as incapable of proof as is the existence of God;

- That animals do have inner life seems to be a rather obvious assertion.

Upon reflection, though, the second, psychological question doesn't seem so unimportant to me after all. Though today no one would be likely to defend the Cartesian position that animals are insensible robots explicitly, this attitude nevertheless still operates implicitly and subconsciously.

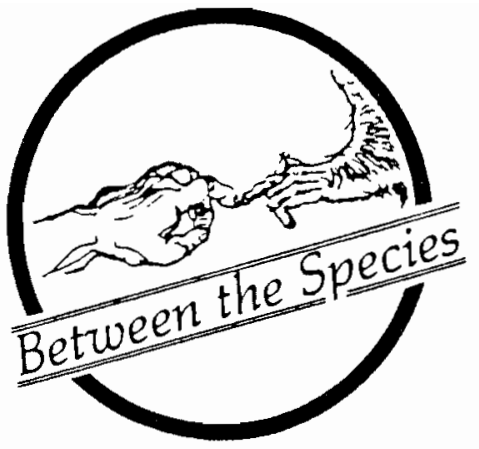

Above all, with respect to animals one can observe a tendency to argue in a way similar to some arguments concerning environmental problems: as measures responding to the depletion of the ozone layer, the greenhouse effect, or increased incidence of leukemia near nuclear power plants are prevented by saying that the causes of these phenomena have not yet been proved sufficiently, necessary measures in favor of animals are similarly prevented by saying that the existence and extent of animal suffering have not yet been sufficiently established.

This being so, the question whether animals have inner life (and to what extent) appears after all to be a question worth dealing with concretely and explicitly. Hence in the following I shall inquire into the question whether animals have conscious, subjective psychological experiences. In short: are animals conscious?

The question, whether animals are conscious, is at bottom hypocritical and superfluous. It is hypocritical, because a large part of what we know conceming the human mind comes from investigations into animals minds: animal research forms a substantial basis of human psychology. Considering this fact and considering the further fact that in the setting of psychology this has been accomplished by the cruelest animal research, it is highly cynical to ask about animal consciousness. On the other hand, the question of animal consciousness is superfluous, because to

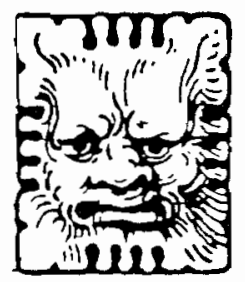


everyone who is not completely crazy, it is already clear that animals also have psychological experience.

The fact that our fellow humans are similar, and feel similarly, to us, is evident in exactly the same sense as mathematical axioms are evident. We are not able not to believe in them. Karl Buhler, who to my knowledge was the first to call attention to these facts, spoke of "you-evidence."

We have the same axiomatic certainty for animals' souls, as we have for supposing in our fellow humans the existence of a soul (which means the ability to experience subjectively). A human who truly knows a higher mammal, perhaps a dog or a monkey, and will not be satisfied that these beings experience similarly to himself, is psychologically abnormal and belongs in a psychiatric clinic, as an impaired capacity for "you-evidence" makes him a public enemy. (Lorenz, 1980, pp. 251, 254)

Animal consciousness was already given voice to by David Hume (1739, quoted in Griffin, 1984, p. 2), who thought it a foregone conclusion: "No truth appears more evident, than that beasts are endow' $d$ with thought and reason as well as men." Also according to Robert Spaemann (1984, p.71) it is well-known "that at least more highly evolved animals can experience conditions which we can describe accurately only with words like pain, suffering, pleasure and well-being." And Adolph Portmann (1987, pp. 112, 116), for whom there can be no doubt that animals have a rich conscious life, poses the question:

May one truly ask in earnest, whether animals have a soul-is the answer not obvious-is it not self evident for everyone whose heart is open to animals, that these creatures are ensouled, that they perceive and experience similarly as we do, that they are subject to moods as we are, that they exhibit attachment and rejection among themselves, as in intimacy with us humans?" (p. 108)

Also for Charles Darwin (1874) there can be no doubt that between humans and higher mammals there is no fundamental difference regarding inner life (ch. 3): "The fact that the lower animals are excited by the same emotions as we are is so well established, that it will not be necessary to weary the reader by many details." (p. 84) After giving examples of love; jealousy, ambition, pride, modesty, rage, and even of animals" sense of humor (p. 86f), he turns to "the more intellectual emotions and faculties" and describes wonder, curiosity, imitation, attentiveness, memory, and understanding of animals. (pp. 87-92) ${ }^{1}$

Without wishing to go into details, one should point to the biological foundation of the psychological similarity between humans and animals (cf. Rollin, 1981, p. 41):

We know with certainty for humans that emotional processes occur in essence in the brain stem and in the limbic system. This, however, is as highly developed in higher mammals as in humans....

Although the anatomy of bird brains is not directly similar to that of mammal brains, it would be very inept not to ascribe intensive mental experiences also to birds. (Lorenz, 1980 , p. 254)

Finally, it should be remembered that the psychological similarity between humans and animals also follows from considerations from evolutionary theory: humans and animals are related; the differences between them are not so much a matter of kind as they are instead a matter of degree, so that "the senses and intuitions, the various faculties ... of which man boasts, may be found in incipient, or even sometimes in a welldeveloped condition, in the lower animals." (Darwin, 1874 , p. 141; cf. Portmann, 1987, esp. pp. $110 f f ., 116$ )

In connection with evolutionary theory, a personal observation: those who most vehemently claim an insuperable gulf between themselves and animals, are in truth the closest to being "animals"!

\section{Pain}

Pain is that psychological phenomenon which is most manifestly experienced by both humans and animals, for at least two reasons. The first is animals' behavior in situations which cause pain to humans. This behavior allows no doubt that they also experience pain. The second reason is that pain has a biological function of protecting from danger: "No higher creatures without pain - but without pain also no higher life: pain is that 
waming which protects our bodies and lives." (Frey, 1978, p. 7) (cf. also Serjeant, 1970, p. 56-62) On that score, it is important to establish that by no means do animals feel pain to a lesser degree than humans do. Rather consider:

\section{All known facts support the assertion that the higher mammals experience pain at least as strongly as we do. It is nonsensical to say that they experience it less because they are lower animals. One can easily show that the senses of animals are much sharper than ours. Birds often see better, nearly all free living animals hear better, others have a more sensitive sense of touch than we do. The sharp perception of a hostile environment is of more vital importance for higher animals that it is for contemporary humans. Apart from the complicated cortex which does not perceive pain directly, the nervous systems of the higher animals are nearly identical with ours. (Serjeant, 1970, p. 99ff. emphasis added)}

Next to the above mentioned physiological aspects there are, however, also still psychological grounds which suggest that in certain circumstances animals feel pain even more intensely than humans. Bernard Rollin (1981, p. 33) points out the possibility that animals in pain experience only pain, without the possibility of anticipating an end to the pain, so that their entire psychological horizon is filled with pain. And Bernhard Grzimek (quoted in Teutsch, 1987, p. 264) writes in reference to animals: "Their pains are much more horrible than ours, for they must suffer them blind and dumb, they know not why or what for. They have no comfort." Also Robert Spaemann (1979, quoted in Teutsch, 1987, p. 264) has himself stated about this issue: "On the one hand, reason can increase pain because it accumulates past and future pain, so to speak. On the other hand, however, reason gives us the ability to dissociate from and overcome pain. To sing psalms on the way into the gas chambersthat no animal can do. They are delivered speechless, in dumb fear, and their fear is nearly always fear of death." Otfried Höffe (1984, p. 85ff., quoted in Teutsch, 1987, p. 264) has also attended to the details of this issue:

Now one could object that the distinguishing feature of humans and animals, the ability to reflect, entails a new relation to pain, especially a higher degree of pain. It is correct that the relation to pain changes, but false that pain in principle increases. The ability to reflect also allows us to foresee an end of pain, oras in the case of a painful cure-to recognize its necessity, which allows us to endure more easily. Beyond this, only humans can ask themselves the question of the sense of life, leading to despair over an apparently meaningless life, but also being able to accept one's life and digesting it creatively. In a word: however much the relation to pain changes with the capacity for reflection, this provides no argument for having less regard for the pain of subhuman creatures than for the pain of humans.

As evident and certain as is the capacity to experience pain among the higher animals, so it is probable, on the other hand, that the further we descend on the evolutionary scale, we end finally somewhere in reflexive, mechanical reactions. We will not here discuss the problem of line-drawing, which is much more a theoretical than a practical concem, but will later discuss it. Mention should be made in this connection of the very serious clues that worms and insects are also clearly capable of pain. (see Rollin, 1981, p. 31ff.; Lockwood, 1988; and Griffin, 1984, pp. 179-195).

\section{Suffering}

However, animals experience not only physical pain, but also psychological suffering: the pain of separation, homesickness, grief, despair, hopelessness, dread, anger. (Bilz, 1974, V, 28; Serjeant, 1970, p. 100) That animals also suffer mentally is not just the personal opinion or invention of sentimental animal lovers, but an indisputable reality. The best evidence of this is that professional animal exploiters who work solely for the "optimal" exploitation of food animals confirm it. So, for example, M. Cena (1978) in his contribution to an anthology on "Farm Animal Production," speaks explicitly of depression, neuroses, psychoses, nervousness, and stress of animals.

What has already been mentioned in reference to physical pain must also be pointed out with respect to psychological suffering, that under certain circumstances animals will suffer more than similarly situated humans. For example, if humans are captured in war, 
we can explain to them that they will be searched and locked up, but that in the meantime nothing else will happen to them and that they will be freed later. But if we capture a wild animal, we cannot communicate to it that we will not kill it. It cannot distinguish between an attempt to overcome it and an attempt to kill it, and thus much the same fright is produced in both situations. (Singer, 1984, p. 76, and 1982, p. 36) Also, Robert Spaemann (1984, p. 78) has stated: "Just because animals cannot integrate their suffering into a higher identity of an intentional life connection, and so master it, they are delivered to their suffering. They are, so to speak, in pain, only pain, before all, if they cannot react through flight or aggression."

\section{Intelligence}

Following the previous theoretical explanations of animal consciousness, we will now turn our attention to some examples of animal behavior. Although these examples are not a proof in the strongest sense of the existence of animal consciousness-such a proof is not possible even in the case of the existence of consciousness in our fellow humans; we will return to this topic later-nevertheless (especially in connection with theoretical considerations) they make animal consciousness so plausible and probable that serious doubts are not possible. We turn next to examples of animal intelligence.

Darwin $(1874$, p. 85$)$ reports the following occurrence:

At the Cape of Good Hope an officer had often plagued a certain baboon, and the animal seeing him approaching one Sunday for parade, poured water into a hole and hastily made some thick mud, which he skillfully dashed over the officer as he passed by, to the amusement of many bystanders. For long afterward the baboon rejoiced and triumphed whenever he saw his victim.

Vitus Dröscher (1987b) reports the following "performance":

A young Canadian beaver performed a real prank. Each morning at the same time with its parents, relatives and older siblings it would forage from a farmer's wife. There the four- legged hooligan wanted the daintiest morsel, always appearing first at the food place.

One day, however, he had wasted time, and as he sprang out of the water, all the adults and older beavers were already pressing at the trough. He ran back to the river and hastily slapped the water three times with his wide tail. In beaver language that is the alarm signal for the highest danger. In a flash all the other beavers vanished, and the young rascal had the food all to himself...

Consider what pertains to the performance of this little beaver: he had to give the alarm and fright signal, without having a real fright of a predator. Hence he had to free himself from the chains of instinctive behavior and act intentionally. He succeeded only through an act of self-reflection: he had to know how his act would affect others to deceive them.

Concerning a rhesus monkey in New York's Bronx Zoo, Dröscher reports:

One day a shrewd fellow was missing from the large monkey rock, and it took a few days before someone found and captured him. The enclosure, the moat, and everything else was examined. Nowhere was a possible escape route discovered. But the next day the deserter was gone again.

Once again, a police contingent set about trapping the animal. And then a keeper laid in wait to discover the monkey's secret escape path. At daybreak he finally saw the animal take a banana from a hiding place. This charitable visitor's gift had been reserved especially for his escape plan. He ran with it to the broad moat, which bordered the moose enclosure, and swung the banana visibly back and forth--just like a scientist, who wished to artfully lure some experimental animal with a food reward.

In fact, a large moose swam over to the rhesus monkey. Quickly putting the banana in his mouth as a ticket, so to speak, the cunning and water-shy fellow sprang onto the moose's broad back and allowed the "boat" to ferry him to the neighboring enclosure. From here the escape was only monkey-child's play. (p. 100ff.) 
Finally, a story which Dröscher reports concerning baboons:

In a free enclosure of a zoo the strongest male ascended to sultan, and forbade the rest of the males to have intimate relations with his "ladies." He endured not even the slightest flirt. Still, he couldn't always stand guard. If he removed anywhere to the shadows of the rock to nap, it could happen that the ladies would two-time with other males. A harem female who had been neglected by the sultan for a long time, began in such an opportunity to openly display all her charms in order to befriend a bachelor.

At just that moment the sultan reappeared, and something incredible happened: as if threatened with murder, the cheater cried out, scrambled loose, gave the still courting male a slap, moaning loudly fled into the arms of the bewildered sultan, and complained to him, looking across at her seducer raging loudly and angrily with her arms beating the ground. And she achieved her goal: the sultan, who for forbidden intimacy usually only punished the female, believed this crafty lie. First he thrashed the blameless bachelor suitably, and then he overwhelmed the "certified sufferer" with affection. (p. 101ff.) ${ }^{2}$

\section{Social Life}

All higher animals demonstrate individuality in behavior, choice, aversion, and preference within social life. In mates which come together to reproduce we see very intimate relations, which are preserved beyond all sexual necessity, and similar relations can be observed between animal parents and their children. All zoos know how the welfare of their wards depends on the effectiveness of such relations. (Portmann, 1987, p. 115)

Concerning the mother-child relation among dolphins, John Robbins (1987, p. 39) reports the following: if dolphin children fall into tuna nets, their mother will follow them for endless stretches, trying to accompany the children as far as possible. If mother and child are caught together in the nets, the mother will stay as near as possible to the children, to sing to them. The tuna fish industry takes note of this only insofar as it has noted that the majority of dolphins found in their nets are female or young. In this way, about 150,000 come to die each year. (O'Barry, 1989, p. 18ff.)

Also in the social life of animals we find types of behavior which it would be absurd not to accept as connected with subjective experience. The basis for animal social life, as with humans, is the ability to give love, the desire to receive love, and the suffering which results from deprivation of loved ones. (See Robbins, 1987, pp. 37-39)

The most impressive proof of animal social life occurring on the level of subjective experience is doubtless the emotional relation between mother and children. Disturbing or preventing these relations leads, as in humans, to severe, lifelong harm, even literally to insanity. One can in no way doubt this conclusion, which grew out of decades of intensive scientific research. The dreadful experiments on monkeys which the American psychologist Harry Harlow carried out are only the best known in this area of research, in which animals are systematically and intentionally caused the most severe mental suffering, in order to achieve new scientific knowledge concerning humans. Thus Harlow and his colleague Stephen Suomi describe

how they had the "fascinating idea" of inducing depression by "allowing baby monkeys to attach to cloth surrogate mothers who could become monsters":

"The first of these monsters was a cloth monkey mother who, upon schedule or demand, would eject high-pressure compressed air. It would blow the animal's skin practically off its body. What did the baby monkey do? It simply clung tighter and tighter to the mother, because a frightened infant clings to its mother at all costs. We did not achieve any psychopathology.

"However, we did not give up. We built another surrogate monster mother that would rock so violently that the baby's head and teeth would rattle. All the baby did was cling tighter and tighter to the surrogate. The third monster we built had an embedded wire frame within its body which would spring forward and eject the infant from its ventral surface. The infant would subsequently pick itself off the 
floor, wait for the frame to return into the cloth body, and then cling again to the surrogate. Finally, we built our porcupine mother. On command, this mother would eject sharp brass spikes over all of the ventral surface of its body. Although the infants were distressed by these pointed rebuffs, they simply waited until the spikes receded and then returned and clung to the mother."

These results, the experimenters remark, were not so surprising, since the only recourse of an injured child is to cling to its mother.

Eventually, Harlow and Suomi gave up on the artificial monster mothers because they found something better: a real monkey mother that was a monster. To produce such mothers, they reared female monkeys in isolation, and then tried to make them pregnant. Unfortunately, the females did not have normal sexual relations with male monkeys, so they had to be made pregnant by a technique which Harlow and Suomi refer to as a "rape rack." When the babies were born the researchers observed the monkeys. They found that some simply ignored the infants, failing to cuddle the crying baby to the breast as normal monkeys do when they hear their baby cry. The other pattern of behavior observed was different:

"The other monkeys were brutal or lethal. One of their favorite tricks was to crush the infant's skull with their teeth. But the really sickening behavior pattern was that of smashing the infant's face to the floor, then rubbing it back and forth." (Singer, 1975, pp. 44-45. Quotations are from Engineering and Science, 33, 6 (April, 1970), p. 8)

\section{Morally Analogous Behavior}

A further proof of animal consciousness, one which is most closely connected to social life and overlaps with it, is so-called morally analogous behavior. The following examples, in my opinion, speak for themselves. The next three reports come from Dröscher (1987a):

In the ocean area of the Lesser Antilles, an adolescent dolphin strayed far beyond the visual range of his troop, and was suddenly attacked by three sharks. Immediately, he burst forth with a series of shrill whistles: SOS signals in dolphin language. The short doublenotes sound like an over-wound alarm siren: the first part increases sharply in musical pitch, the second falls as harshly.

The result was amazing. The group of dolphins (approximately 20), chatting with whistling, screaming, grunting, gurgling, growling and squeaking sounds, immediately stopped their conversation. As in an emergency call in shipping, there was absolute radio silence. Then the animals shot in greatest haste at $60 \mathrm{~km} / \mathrm{hr}$ to the area of the surprise attack. The male dolphins rammed the sharks with undiminished speed. They dealt crashing blows to their sides until the sharks were crushed and sank to the deep bottom of the Caribbean Sea with broken bones and cartilage.

During the struggle, the females endeavored to help the disabled adolescent dolphin, who could no longer surface on his own strength. Two took him between them, pushing him under his vertical fins and holding him so high that the blow hole on his head projected out of the water and the disabled one could breathe again. By reciprocal whistling signals the helping maneuver was accomplished exactly. From time to time they would relieve the stretcher bearers. Once it was observed how this indefatigable rescue work went on continuously day and night for a full two weeks, until the injured dolphin was healthy and back to his original strength. (p. 95ff.)

A chimpanzee was seriously wounded by a hunting party and plunged to the ground. As he thereupon let out a cry for help, the other members of the troop surrounded him, raised him up, propping him in an unbelievable human manner, and urged him with gentle sounds to go with them. While this was occurring, a strong ape threw himself, screeching loudly, between the sick transport and the hunters. Only when he heard through repeated shouts from his companions that they had found protection in a thick wood, he removed himself to safety. (p. 96) 
Especially astonishing is the fact that chimpanzees do not manifest solidarity only with their own kind. As a Dutch researcher tied a chick in the path of a virgin forest, the robust chimpanzees also freed this chirper, gracefully removing the chain, and being certain not to injure the delicate legs of the small bird. (p. 97)

James Rachels (1976, p. 215ff.) tells of a diabolical experiment that was conducted in the United States with rhesus monkeys. The details of the experiment should not be gone into here. It is enough to briefly represent the basic conception and the results of the experiment. Two animals would be placed in an experimental device, with a glass wall separating them in the middle. The animal on one side had the possibility of obtaining food by operating a lever. The floor of the section on the other side, where the second animal was, could be delivered a current, which would give this animal a strong and very painful electric shock. Now the experiment was set up in such a way that, every time the first animal pressed the food lever, the second animal would receive a strong electric shock. In this manner it could be established whether and to what degree the first animal would renounce food in order to spare its conspecific an electric shock. It appeared that a distinct majority of experimental animals placed in the compartment with the food lever preferred to go without food for days rather than to deliver an electric shock to the animal present on the other side.

E. Gavin Reeve (1978, p. 562) reports a mongrel, Blackie, who had tried in vain to rescue Ian, a fourmonth infant, from a burning house. Both perished in the flames. Although no one observed the dog's brave rescue attempt directly, clear traces were left behind: light impressions of his teeth on the baby's shoulder, from when he was trying to pull Ian from the fire.

The fire broke out in the kitchen. While the mother hastened to her two other children, Blackie ran into Ian's bedroom. The mother heard a bump which probably was the striking of the child, as the dog pulled him from his bed onto the floor. The dead child was found only a few centimeters from Blackie's outstretched paws. The dog had come to the family first a year previous. After the birth of Ian, he sat most frequently next to the child's bed.

\section{Three Objections}

By now it should be clear to everyone that animals are not unconscious automata, but feeling creatures with conscious psychological experience; may I conclude by considering three objections which are frequently produced in this area:

\section{"There is no clear demarcation between conscious and unconscious creatures."}

This objection is just as correct as it is unimportant. Such questions of line drawing arise everywhere in life, without creating serious uncertainty in our decisions. Between warm and cold, poor and rich, right and wrong there is also no clear, unequivocal boundary. Nevertheless, that there is no unquestioned line to be drawn for these conceptions gives us no great difficulty as a rule. We know what is meant by talk of warm food, rich people or wrongful activity.

And so it is also concerning the question which creatures have psychological experience: no reasonable person would wish to seriously maintain that dogs, cats, apes, pigs, cows, and chickens (and all other animals concerning which the well known animal protection questions are asked) do not suffer if we poison, gas, burn them, place them in lifelong captivity, or brutally kill them. And the decisive point in connection with our question is not that it is uncertain where the boundary between conscious and unconscious creatures exactly lies, but that it is certain that it does not lie between humans and animals.

\section{"We have no access to animal consciousness, because animals cannot speak."}

Obviously, language is of enormous importance in human life. And it would be absurd to put into question the towering role that language has for the entirety of human evolution and culture. However, in concrete interpersonal communication, verbal language is neither the sole, nor always the best, way of communicating. And therefore the impossibility of speaking with animals is no fundamental hindrance to access to animal experience. Bernard Rollin (1983, p. 111 , and 1981, pp. 36ff., 55, 57) calls attention in this connection to the following facts:

In a certain sense animal psychic life is even more easily accessed than is that of other humans, because 
it is more simply structured. While human needs are determined socially, culturally, and historically, and therefore correspondingly variable in form, animal needs are simpler and more stable. Due to the simpler structure of animal psyche, there are also fewer sources and possibilities of deception. Nonverbal animal behavior is of ten a more reliable indicator of experience and desires than human speech is; animal lies are very infrequent.

Also, an important part of human communication takes place on a nonverbal level. All lovers know that in the critical and decisive moments linguistic communication breaks down and feelings and moods are best brought to expression through a glance, a gesture, or a touch. And the earliest and most important human communication succeeds long before we can speak: namely, in the empathetic relation between mother and child. Here in a subtle and complex manner psychic experience is communicated, without the child being able to use a single word. This early, perfectly functioning mother-child relation is the best and most impressive proof that communicative and cognitive equivalence of two creatures is not a presupposition of functioning communication between them.

\section{"The existence of animal consciousness cannot be scientifically established."}

This objection is correct. But it holds not only for animal consciousness, but for all consciousness outside our own, which means it holds also for the consciousness of other humans. Their subjective experience is not objective or provable either, bccause our knowledge of the expericnce of others is necessarily always based on an analogical argument (which is certainly very probable, but never can conduct us to absolutely certain conclusions): because our fellow humans are obviously similar to us, and because they react similarly to us in similar situations, we reasonably conclude that they also experience similarly to us. However, ultimately, all subjective experience is bound to the subject, and we have no possibility of direct access to this experience. Logically, all other humans could be completely spiritless, thoughtless, and unconscious robots acting from complicated computer programs and a complex mechanism, which only impart the appearance of being humans with conscious psychological experience. "Pure logic cannot refute solipsism-the view that I am the only conscious, thinking creature." (Griffin, 1984, p.39)

We can have ultimate certainty concerning neither animal experience nor the experience of other humans. In both cases we are directed to probabilistic and analogical arguments. Referring to this, there are no relevant differences of principle between the problems and the possibilities of grasping animal experience, and the problems and possibilities of grasping human experience. We must in both cases use the same epistemological and methodological measures, and must not demand in regard to grasping animal experience a logical and methodological standard which in the case of humans is neither attainable nor expected (cf. Teutsch, 1987, p. 14; Sambraus, 1982, pp. 24-27; Lorenz, 1980, p. 251; Griffin, 1984, p. 38ff.):

Many of the objections to the exploration of thought and feelings of animals ... seem to be based on a kind of species solipsism. It may be logically impossible to refute the assertion that all animals are thoughtless robots. But we can escape this paralyzing dilemma, if we rely on the same criteria of reasonable plausibility by which we acknowledge the consciousness of other humans. (Griffin, 1984, p. 39)

That animals have consciousness is as certain as it is certain that other humans have consciousness. And whether animals have immortal souls is as uncertain as it is uncertain whether humans have immortal souls. The question whether animals have immortal souls is, however, not only factually uncertain, but also morally unimportant. In any case, no support can be found for the assumption that, should animals lack immortal souls, we may therefore treat them worse. (See Regan, 1987, p. 69; cf. Rollin, 1981, p. 6ff, as well as 1983, p. 107).

How long a creature lives is unimportant for the question how we should treat it while it lives. If a dog has been hit by an auto and we can mitigate its pain, then we should do so. It would be grotesque to say: "We need not help him, as he will not live forever anyway." It is no less grotesque to say that we have no moral obligations to animals, because they have no life after death. If from this fact anything follows, then it is exactly the opposite: if animals only have this life, then we should do everything possible to 
make the life they have as good as possible. Moreover, having no prospect of a life after death, they also have no prospect of reparation for wrongs which we cause them. Therefore, one could argue, as animals lack immortal souls, we should therefore treat them even better than humans who may hope for compensatory justice in another world!

In conclusion, the question whether animals have souls or not is absolutely unfit for any polemics against the moral status of animals. That animals do have souls in the psychological sense we know, and whether they have souls in the religious sense is-at best -irrelevant.

"Haben Tiere eine Seele?" translated by Lawry Finsen (University of Redlands, Redlands, CA) with many helpful suggestions from Helmut Kaplan. Wherever Kaplan quotes a text the original of which is in English, the original English has been substituted. Bibliographic references have been changed to reflect these sources, rather than their German translations.

\section{Endnotes}

${ }^{1}$ May I call attention to Griffin (1984) and Regan (1984) as important and interesting sources concerning animal consciousness. Griffin supplies (in chapter 1) a list of proofs of animal consciousness in general and mentions also that there is quite a bit of evidence that insects are conscious. Regan provides (in chapters 1 and 2) a detailed and wellgrounded presentation from the biological, philosophical, and historical points of view.

\footnotetext{
${ }^{2} \mathrm{~A}$ rich number of further examples of lies and deception in apes can be found in Blick Züruck (1988). Conceming the spectacular research with apes and human language, especially the sign language used by the deaf and dumb (cf. Jenkins, 1976), I will not here consider that research, since its results have recently been judged controversial (cf. "Affen: Lug Und Trug...," 1986) and the research now is concentrating on characteristic communication (cf. ibid.). While the inquiries into language among apes especially-be it human or ape language - and among animals in general are very interesting, they have no central importance concerning the theme of animal consciousness, for language is by no means a presupposition of conscious experience. (Cf. here also Regan, 1987, p. 37ff.; Singer, 1984, pp. 130-133; and Rollin, 1981, pp. 24-27). Finally, may I yet refer to two highly interesting sources concerning the theme of animal intelligence in general: Regan, 1976, p. 5ff., likewise discussing the role of language, and Robbins, 1987, pp. 40-42.
}

\section{Bibliography}

"Affen: Lug und Trug Nach Menschenart," Der Spiegel, 31, 1986 .

Bilz, Rudolph, "Studien uber Angst und Schmerz," Paläonthropologie Band 1/2 (Frankfurt/M.: Suhrkamp, 1974).

"Blick Züruck," Der Spiegel, 5, 1988.

Cena, M., "Die Ethologie der Nutztiere in der tierärztlichen Diagnostik." In D. W. Fölsch (ed.), The Ethology and Ethics of Farm Animal Production (Basel: Birkhauser, 1978).

Darwin, Charles, The Descent of Man (New York: P. F. Collier and Son, 1874).

Dröscher, Vitus, "Berichte, die nachdenklich machen." In Gotthard M. Teutsch (ed.), Da Tiere eine Seele Haben... (Stuttgart: Kreuz, 1987a).

Dröscher, Vitus, "Lugen Haben Vier Beine." In Gotthard M. Teutsch (ed.), Da Tiere eine Seele Haben... (Stuttgart: Kreuz, 1987b).

Frey, Rudolph, Geleitwort zu Ronald Melzack, Das Ratsel des Schmerzes (Stuttgart: Hippokrates, 1978).

Griffin, Donald, Animal Thinking (Cambridge: Harvard University Press, 1984).

Höffe, Otfried, "Ethische Grenzen der Tierversuche." In Ursula M. Händel (ed.), Tierschutz: Testfall unserer Menschlichkeit (Frankfurt/M.: Fischer, 1984).

Hume, David, A Treatise of Human Nature (London: Oxford University Press, 1988 [1739]).

Jenkins, Peter, "Teaching Chimpanzees to Communicate." In Tom Regan and Peter Singer (eds.), Animal Rights and Human Obligations (Englewood Cliffs, N. J.: PrenticeHall, 1976).

Lockwood, Jeffrey A., "Not to Harm a Fly: Our Ethical Obligations to Insects," Between the Species, 4, 3, 1988.

Lorenz, Konrad, "Tiere und Gefühlmenschen," Der Spiegel, 47, 1980.

O'Barry, Richard, "Dolphins in Captivity: Wasted Lives, Wasted Minds," Animals' Agenda, March, 1989.

Portmann, Adolph, "Haben Tiere eine Seele?" In Gotthard M. Teutsch (ed.), Da Tiere eine Seele Haben... (Stuttgart: Kreuz, 1987).

Rachels, James, "Do Animals Have a Right to Liberty?" In Tom Regan and Peter Singer (eds.), Animal Rights and Human Obligations (Englewood Cliffs, N. J.: PrenticeHall, 1976).

Reeve, E. Gavin, "Speciesism and Equality," Philosophy, 53, 1978.

Regan, Tom, "But for the Sake of Some Little Mouthful of Flesh," in Tom Regan, The Struggle for Animal Rights (Clark's Summit, PA: International Society for Animal Rights, 1987).

Regan, Tom, The Case for Animal Rights (London: Routledge \& Kegan Paul, 1984). 
Regan, Tom, Introduction to Tom Regan and Peter Singer (eds.), Animal Rights and Human Obligations (Englewood Cliffs, N. J.: Prentice-Hall, 1976).

Robbins, John, Diet for a New America (Walpole, N. H.: Stillpoint Publishing, 1987).

Rollin, Bernard E., Animal Rights and Human Morality (Buffalo: Prometheus, 1981).

Rollin, Bernard E., "The Legal and Moral Bases of Animal Rights." In Harlan B. Miller and William H. Williams (eds.), Ethics and Animals (Clifton, N. J.: Humana Press, 1983).

Sambraus, H. H., "Ethologische Grundlagen einer Tiergerechten Nutztierhaltung." In D. W. Fölsch und A. Nabholz (eds.), Ethologische Aussagen zur artgerechten Nutztierhaltung (Basel: Birkhauser, 1982).

Serjeant, Richard, Der Schmerz: Warnsystem des Korpers (Bergisch Gladbach: Lubbe, 1970).

Singer, Peter, Animal Liberation (New York: New York Review Books, 1975).

Singer, Peter, Praktische Ethik (Stuttgart: Reclam, 1984).

Spaemann, Robert, "Bestialische Quälereien Tag für Tag," Deutsche Zeitung, 33, 1979.

Spaemann, Robert, "Tierschutz und Menschenwürde." In Ursula M. Händel (ed.), Tierschutz: Testfall unserer Menschlichkeit (Frankfurt/M.: Fischer, 1984).

Teutsch, Gotthard M., Mensch un Tier: Lexikon der Tierschutzethik (Göttingen: Vandenhoeck \& Ruprecht, 1987).

\section{Biographical Note on Helmut F. Kaplan}

Helmut F. Kaplan has advanced degrees in Psychology (D. Phil.) and Philosophy (Mag. Phil.) from the University of Salzburg, and currently lives in Salzburg. He is one of the very few intellectuals working on animal rights issues in the German-speaking world. His publications include Philosophie des Vegetarismus: Kritische Würdigung und Weiterführung von Peter Singers Ansatz (or, The Philosophy of Vegetarianism: A Critical Assessment and Continuation of Peter Singer's Beginning), 1988, as well as Warum Vegetarier: Grundlagen einer Universalen Ethik (or, Why Vegetarian: Foundations of a Universal Ethic), 1989 (both published by Peter Lang, Frankfurt/M.). He has most recently been working on a book on the topic of the Principle of Equality.

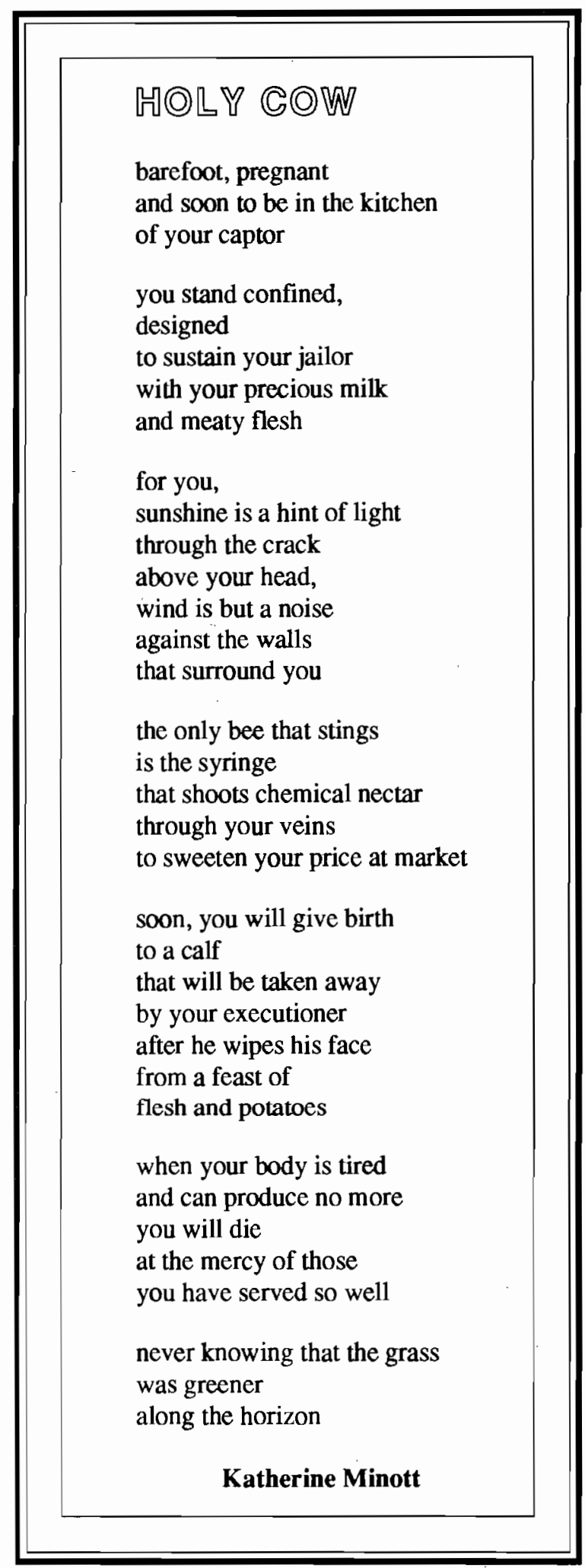

